\title{
Economic, Regulatory and Social Aspects Related to Wastewater Ocean Disposal through Submarine Outfalls
}

Dr. Menahem Libhaber

DOI 10.4322/dae.2016.008

\section{Abstract}

The receiving body of wastewater and effluents of coastal cities is, in most cases, the ocean or the sea. For the most part, two wastewater management strategies are applied in coastal cities: (i) provision of secondary level wastewater treatment followed by effluent discharge to the sea via a short submarine outfall; and (ii) provision of preliminary level wastewater treatment followed by effluent discharge to the sea via an effective submarine outfall. A comparison between the two strategies is presented in the article, leading to a conclusion that Strategy (ii) of preliminary treatment followed by an effective outfall is economically, environmentally and socially superior. A preliminary treatment plant followed by an effective outfall is simple to operate and presents a low public health risk and a low level of negative environmental impacts. Many outfalls systems of this type are successfully functioning and have a proven track record in many coastal cities all over the world. For developing countries it is the essential solution since such countries cannot afford executing high investments in complex and unnecessary wastewater treatment plants. This strategy should be coupled with a sea water quality monitoring program beginning prior to and continuing after the construction of the outfall system, to verify the performance of the system and to determine if a higher than preliminary treatment level is necessary. This is a logical approach which prevents costly investments in unnecessary treatment installations.

Keywords: Submarine Outfalls, Marine Wastewater Outfalls, Wastewater Treatment

\section{Sumário}

Na maioria dos casos, o corpo receptor de esgotos e efluentes de cidades costeiras é o oceano ou o mar. Duas estratégias para a gestão dos esgotos em cidades costeiras são geralmente aplicadas: (i) tratamento secundário do esgoto seguido por descarga do efluente ao mar através de um emissário curto; ou (ii) tratamento preliminar do esgoto seguido por descarga do efluente ao mar através de um emissário eficaz. Neste artículo é apresentada uma comparação entre as duas estratégias, concluindo-se que a segunda Estratégia (ii) é superior em termos econômicos, ambientais e sociais. Uma Estação de Tratamento de Esgotos (ETE) de nível preliminar seguido por um emissário eficaz é simples de operar e apresenta um baixo risco para a saúde pública, bem como um baixo nível de impactos ambientais negativos. Muitos sistemas deste tipo estão em operação em cidades costeiras no mundo, com um histórico comprovado. Para países em desenvolvimento é uma solução essencial posto que este tipo de países não podem se permitir executar altos investimentos exigidos por complexas e desnecessárias ETEs. Esta estratégia deve ser executada em paralelo com um programa de monitoramento da qualidade da água do mar, iniciando antes e continuando depois da construção do sistema do emissário, para verificar o desempenho do sistema e para determinar se um nível maior que tratamento preliminar é necessário. Este e um enfoque lógico que previne a realização de altos investimentos em instalações de tratamento desnecessárias.

Palavras-chave: Emissários Submarinos, Tratamento de Esgoto. 


\section{THE DILEMMA OF SELECTING THE STRATEGY FOR WASTEWATER MANAGEMENT IN COASTAL CITIES}

South and Central America are bordered by two oceans, the Pacific in the east and the Atlantic in the west, with very long shorelines and coastal zones. The Caribbean Islands are surrounded by seawater. The American continent is also crossed by some very large rivers with a high autopurification capacity. Many cities in Central and South America are coastal cities, as are most of the cities in the Caribbean Islands. About $30 \%$ of the urban population of cities with more than 100,000 inhabitants in Latin America resides near the coast or near estuaries (UN 2003). The receiving bodies of wastewater and effluents of coastal cities are the ocean or the sea, except in cases where effluents are needed for reuse purposes (and those are few in Latin America).

In broad terms, two wastewater management strategies are applied in coastal cities:

i. Provision of secondary level wastewater treatment or superior followed by effluent discharge on the beach or to the sea via a short submarine outfall

ii. Provision of preliminary level wastewater treatment followed by effluent discharge to the sea via an effective submarine outfall (an effective outfall being defined as an outfall which provides a near field dilution of at least 1:100)

Preliminary treatment preceding a submarine outfall consists of coarse screening, grit removal and fine screening. Such treatment is sometimes referred to as advanced preliminary treatment because it contains the fine screening unit, which is not included in preliminary treatment that forms part of a secondary treatment plant (and is not necessary in such case).

In most countries in Latin America and the Caribbean (LAC), environmental legislation enforces application of Strategy (i). In spite of such legislation, in several cases coastal cities have applied Strategy (ii). Ways for achieving legal authorization for such an approach are discussed below.

In most LAC countries, legislation referring to effluent quality is defined by two independent norms: (i) effluent quality defined by the maximum permissible limits of certain contaminants in the effluent; and (ii) receiving bodies' water quality, which defines the quality of various types of surface water which cannot be surpassed when effluents are discharged into these receiving bodies. There is no direct relation between the two norms. Norm (i) can be complied without complying with norm (ii) and vice versa. The requirement is to comply with both simultaneously. Norm (i) is a message that wastewater must be treated before it is discharged to the environment. Norm (ii) is the important norm which ensures the protection of surface waters and indirectly defines the level of wastewater treatment required in each case for protecting the quality of those waters.

In most cases, the seawater quality defined by norm (ii) can be achieved by applying management strategy (ii): preliminary level treatment followed by effluent discharge to the sea via an effective submarine outfall. Complying with norm (i) which requires a higher than preliminary level of treatment is not necessary for achieving the seawater quality accepted by norm (ii), but the requirement to comply with both norms simultaneously renders the application of the management strategy of providing only preliminary treatment as being unacceptable (or illegal).

A comparison between the two strategies (preliminary treatment followed by an effective outfall versus secondary treatment) is presented below; leading to a conclusion that Strategy (ii) of preliminary treatment followed by an effective outfall is economically, environmentally and socially superior. The economic superiority is of special impor- 
tance for developing countries because developed countries have the economic capacity to finance higher than preliminary treatment plants even if it is unnecessary, while developing countries cannot afford such a behavior.

\section{WASTEWATER CONTAMINATES AND THEIR FATE IN THE SEA AFTER BEING DISCHARGED THROUGH A SUBMARINE OUTFALL}

Municipal wastewater contains $99.9 \%$ water and $0.1 \%$ other materials, part of them contaminants. Effluents of wastewater treatment plants (WTP) contain less than $0.1 \%$ of other than water materials. The principle contaminants in municipal wastewater and effluents are: floating matter, suspended solids, organic matter represented by Biochemical Oxygen Demand (BOD), pathogenic organisms represented by the indicator organism fecal coliform, nutrients (nitrogen and phosphorous) and a variety of persistent toxic contaminants (toxics organics and traces of metals).

The importance of each contaminant in terms of its environmental impact depends on the type of the wastewater or effluent receiving body. If the receiving body is a river, the critical contaminants are BOD (which can deplete the oxygen from the river water) and pathogens. If the receiving body is a lake, the critical contaminants are nutrients, which may cause eutrophication. In the case of the sea as a receiving body, the critical contaminants are pathogens, floating material and large diameter suspended solids. This conclusion results from the fate of the contaminants in the seawater.

What is the fate of the mentioned contaminants in seawater? Non-degradable floating matter continues to float. BOD is diluted and decomposes in the oxygen saturated marine environment, mainly through biological decomposition. Suspended solids of small diameter are diluted and their organic fraction, which is BOD, undergoes biological decomposition. Bacteria are dilutes, float and are destroyed by the ultraviolet radiation of the sun.
Nutrients are diluted but do not decompose, and the persistent micro-contaminants are diluted and do not decompose.

Considering the above, it becomes clear that the critical contaminates related to wastewater discharge to the sea are: (i) bacteria, which in spite of the dilution remain in high concentration due to their very high concentration in the raw wastewater (of about 106-107 MPN/100ml); (ii) non-degradable floating matter which continues to float and does not decompose; and (iii) large diameter suspended solids which continue to float for a long time. Other contaminants such as BOD are diluted to very low levels and decompose with time. Nutrients and micro-contaminants do not decompose but are diluted to very low concentrations.

Since BOD is not a critical contaminant, it is not necessary to remove BOD prior to discharge of effluent to the sea. Given that the main function of secondary or higher level of treatment is removal of BOD, it is doubtful that secondary or higher level of treatment is necessary prior to effluent discharge to the sea.

Based on the considerations presented above, the strategy for the management of wastewater when the effluent receiving body is the sea is surging to be the following:

- Removal of the following contaminants from the wastewater is required prior to the discharge of the effluent to the sea: (i) floating matter; (ii) coarse suspended solids; and (iii) toxic micro contaminants.

- The discharge of effluent into the sea needs to be done in such a manner that ensures a high level of dilution of the effluent in the seawater.

With the application of this strategy floating matter, coarse suspended solids and toxic micro contaminants do not reach the sea, the BOD is diluted and decomposed in natural process at sea, pathogens are reduced to acceptable levels by dilution 
and solar radiation, and nutrients are diluted to levels that do not present risks to the marine environment.

The main source of toxic micro contaminants in municipal wastewater is industrial wastes. These toxics are not removed even by secondary treatment. and must be treated in the source by the industries that generate them.

The level of treatment which is compatible with the management strategy presented above is the advanced preliminary treatment. A higher level of treatment such as secondary or higher is not required and would not have any positive effect if the effluent is discharge through an effective outfall, because the main achievement of secondary treatment is BOD removal, and in this case, BOD removal is unnecessary.

\section{THE SUBMARINE OUTFALL AS A WASTEWATER TREATMENT UNIT}

The density of municipal wastewaters and effluents is close to that of water and is lower than that of the saline seawater. Due to this density difference, wastewater or effluent which is discharged at the bottom of the sea floats up to the surface (like oil in water) creating an up-cone which causes entrainment of seawater into it and results in a high dilution of the effluent. The dilution of the up flowing effluent is termed the near field dilution or initial dilution. Once the effluent reaches the sea surface, the action of the waves and sea currents causes a second type of dilution, the far field dilution. The resulting total physical dilution of the effluent is the multiplication of the near and far field dilution values. It is not possible in this article to get into the details of the hydrodynamic models of the near and far fields but ample information on this subject can be found in the book by Roberts, Libhaber et al (2010). The near field dilution depends on the depth of the effluent discharge point (i.e. on the slope of the bottom of the sea in front of the wastewater generating city) and on the sea current field characteristics (velocity and direction) in the effluent discharge zone. Most of the submarine outfalls discharge the effluent at a depth of at least $\mathbf{2 0}$ meters. A near field dilution of 1:100 is usually achieved at such a depth, and frequently a much higher dilution. The length of most of the existing outfalls in the world is usually in the range of $0.5-4 \mathrm{Km}$. The far field dilution is usually in the range of 3-10. The resulting overall physical dilution caused by discharge of an effluent from a well-designed outfall is between one to several hundreds and one to several thousand. In the case of bacteria contained in the effluent, in addition to the physical dilution, they undergo biological decay due to their extinction in the seawater, mainly as a result of the UV radiation of the sun. The decay of the bacteria is very fast. In most cases ninety percent die out in less than an hour. So the total dilution of bacteria is much higher than the dilution of other constituents in the effluent. This is very important because the concentration of bacteria in the effluent (if disinfection is not applied before the discharge to the sea) is much higher than that of the other constituents. The near field dilution of an effective outfall is equivalent to at least $99 \%$ removal of all contaminants, and with far field dilution it can reach $99.9 \%$ removal of all contaminants.

Secondary treatment (activated sludge or equivalent) usually provides for BOD and Total Suspended Solids (TSS) a dilution of 1:5 to 1:10 (usually the inflow BOD and TSS concentrations are around $200 \mathrm{mg} / \mathrm{l}$ each and effluent BOD and TSS concentrations are $2030 \mathrm{mg} / \mathrm{l}$ each). For other constituents of non-organic nature secondary treatment provides a lower level of dilution because they are not removed by the activated sludge process. As to bacteria, the activated sludge process itself practically does not remove bacteria. It removes about half an order of magnitude, which in terms of dilution translates to a dilution of $1: 2$ for bacteria. Considering the high concentration of bacteria in wastewater, such a level of removal is 
meaningless. Usually an activated sludge effluent undergoes disinfection, and with that, a high level of bacteria dilution is achieved. However, in emergency cases (which may occur quite frequently) disinfection installation go out of operation due to lack of chlorine or malfunctioning of UV lamps, and in such cases, the bacteria dilution of activated sludge plants is practically nonexistent. In terms of design safety, secondary treatment needs to be considered as a process which does not remove bacteria. In fact, the effluent of a secondary treatment plant needs necessarily to be discharged to the sea through an effective outfall (and not through a short outfall) as a protective measure against bacteria contamination during disinfection failure periods.

Comparing the performance of an activated sludge treatment plant to that of an effective submarine outfall system (which includes the preliminary treatment unit, the outfall and the dilution in the nearfield zone surrounding the outfall discharge area) it becomes clear that an outfall system is not just a pipe which transports liquid but rather a very effective treatment unit. The mechanisms of performance of the outfall system as a treatment unit are: (i) the preliminary treatment installations eliminate the contaminants which the sea cannot process: floating matter, gross solids and toxic micro-contaminants (which are in fact eliminated in the source); (ii) the effective outfall causes a high physical dilution of all contaminants, most of them to level acceptable by seawater quality standards; (iii) the marine environment causes further decay of bacteria and decomposition of organic matter (BOD). Consequently, removal on shore of BOD, fine suspended solids and pathogenic bacteria by a treatment plant more advanced than preliminary is unnecessary.

Unfortunately, the outfall system is considered by laymen to be just a pipe, and usually the decision makers in charge of selecting the wastewater management strategy are laymen.
BENEFITS OF THE STRATEGY OF PRELIMINARY TREATMENT FOLLOWED BY AN EFFECTIVE SUBMARINE OUTFALL

Strategy (ii) based on preliminary level treatment followed by an effective submarine outfall has several advantages in relation to Strategy (i) which is based on secondary level treatment. These advantages include economic, environmental, sustainability and social aspects.

In terms of investment cost Strategy (i) is usually much more expensive than Strategy (ii), in a ratio ranging from 6 to 15, depending on the marine characteristics. The specific ratio in each case depends to a large extend on the bathymetry of the sea at the vicinity of the coastal city. As the slope of the sea bottom is steeper, an effective outfall can be shorter and the economic benefit of strategy (ii) becomes higher.

But the economic benefit of Strategy (ii) is not manifested only by the investment cost benefit. Perhaps more important is its O\&M (Operation and Maintenance) benefit. The O\&M annual cost of Strategy (i) is 10 to 20 times more expensive than that of Strategy (ii). Usually the O\&M cost of an activated sludge plant is about 10 US\$/Year/Capita while data from several Strategy (ii) schemes (Cartagena in Colombia and Taboada in Lima, Peru) indicate that the O\&M costs of an effective outfall system is in the range of 0.5-1.0 US\$/Year/Capita. A water and sanitation utility can, in many cases, mobilize investment costs for wastewater treatment installations through government investment subsidies and soft loans. But O\&M costs are usually not subsidized, so the adoption of Strategy (i) imposes a continuous heavy financial burden on a utility, while Strategy (ii) is much more convenient from the financial standpoint.

Strange as it may sound, Strategy (i) is also advantageous from the environmental standpoint. As explained, Strategy (ii) is equivalent, in terms of its impact on the seawater quality, to strategy (i) if both include an effective outfall, and is superior to 
strategy (i) ifstrategy (i) includes only a short outfall or no outfall at all. But in terms of on-land environmental impact Strategy (ii) is advantageous. First, the preliminary treatment plant of Strategy (ii) has a foot print of about 2-5\% of that of a secondary treatment plant of Strategy (i). That in itself represents a significant environmental benefit. A secondary treatment plant also generates large quantities of excess biological sludge, which presents a serious environmental problem, while the preliminary treatment plant of Strategy (ii) generates a small quantity of mostly inert solids that are easy to handle. Secondary treatment plants also generate unpleasant odors in their vicinity; while preliminary treatment installations can be (and usually are) located within closed structures with odor control, so that they do not impose any problem to the environment. As an example, Figure 1 shows the preliminary treatment plant of the city of Cartagena, Colombia, with a capacity of serving a population of about 1.3 million, located inside a modern-style building, posing no nuisance to the environment.

The adoption of strategy (ii), which means operation of an on-land preliminary treatment plant contributes significantly to improving the sustainability of the utility in charge of wastewater management, in several forms: (a) by improving the financial sustainability of the utility due to reduced investment and reduced O\&M costs of the wastewater management installations; (b) by improving the technical and operational sustainability of wastewater treatment installations through the use of a process simple to operate and maintain, based on simple equipment, mostly locally manufactured; and (c) by improving the institutional sustainability of the utility, since as a result of the limited economic demand and technical efforts required for operating the installations, which do not require significant managerial attention, wastewater management does not impose additional administrative efforts in the utility and therefore reduces the burden on the utility's management, thus improving its sustainability.

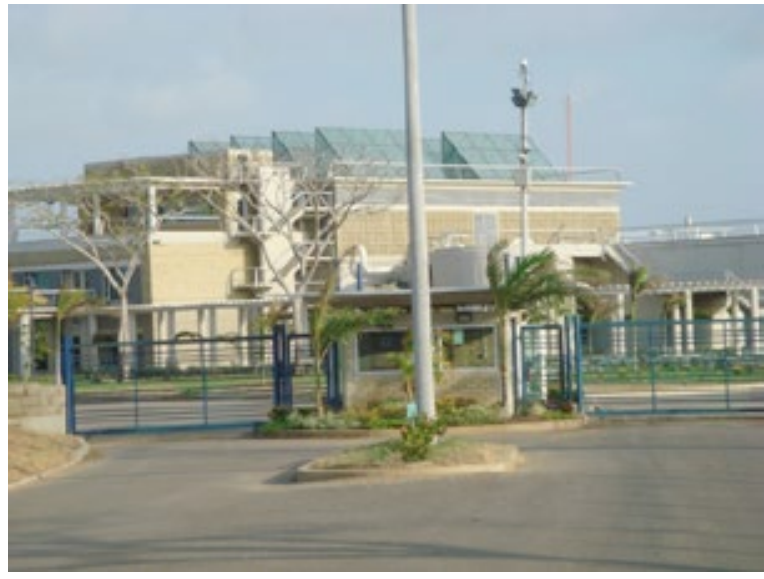

Figure 1: Photo of the Preliminary Treatment Plant of Cartagena, Colombia, Located Inside a Modern-Style

Building, Posing no Nuisance to the Environment

The use of preliminary treatment helps, in fact, in alleviating the principal problems of the water and sanitation sector in developing countries, which are: financial weakness, low technical capacity and institutional weakness, thus contributing to improving sector sustainability.

Wastewater management Strategy (ii) also provides social benefits. It enables reaching a solution to the wastewater problem of a city in an expedited form (sine a requirement of a much larger investment might delay the provision of a solution) and it saves a lot of investment funds, enabling directing the saved funds to solve other social problems, such as providing to the poor improved housing, education etc.

For coastal cities, wastewater disposal by preliminary treatment followed by an effective submarine outfall is an affordable, effective, and reliable solution. It is simple to operate and presents a low public health risk and a low level of negative environmental impacts. Many outfalls systems of this type are successfully functioning and have a proven track record in many coastal cities all over the world. For developing countries it is the essential solution since such countries cannot afford executing high investments in complex and unnecessary wastewater treatment plants. Coastal com- 
munities and authorities in developing countries need to accept that the concept of wastewater disposal by preliminary treatment followed by an effective submarine outfall is an excellent start which is superior to doing nothing.

This strategy should be coupled with a sea water quality monitoring program beginning prior to and continuing after the construction of the outfall system, to verify the performance of the outfall system and to determine if a higher than preliminary treatment level is necessary. This is a logical approach which prevents costly investments in unnecessary treatment installations.

\section{THE POSITION OF THE WORLD HEALTH ORGANIZATION}

The issue of human health risk caused by discharge of wastewater to the sea depends on how the wastewater is discharged. This issue was addressed by the World Health Organization (WHO, 2003) in its guidelines for recreational water quality. The WHO findings are summarized in Table 1 for the major types of treatment and disposal practiced by coastal communities around the world. The table clearly shows that secondary treatment without an outfall or with a short outfall poses a high risk to human health. Secondary treatment followed by an effective outfall poses a low risk, the same as preliminary treatment followed by an effective outfall.

Table 1: Risk to human health from exposure to sewage (Including storm water runoff and combined sewer overflows) (WHO, 2003)

\begin{tabular}{|c|c|c|c|}
\hline \multirow[b]{2}{*}{ Treatment Process } & \multicolumn{3}{|c|}{ Human health risk } \\
\hline & $\begin{array}{l}\text { Discharge } \\
\text { directly } \\
\text { on beach }\end{array}$ & $\begin{array}{l}\text { Discharge } \\
\text { from short } \\
\text { outfall }^{\mathrm{a}}\end{array}$ & $\begin{array}{c}\text { Discharge from } \\
\text { effective } \\
\text { outfall }^{\mathbf{b}}\end{array}$ \\
\hline None $^{c}$ & Very high & High & $N A^{d}$ \\
\hline Preliminary & Very high & High & Low \\
\hline Primary (including septic tanks) & Very high & High & Low \\
\hline Secondary & High & High & Low \\
\hline Secondary plus disinfection $^{e}$ & - & - & - \\
\hline Tertiary & Moderate & Moderate & Very low \\
\hline Tertiary plus disinfection ${ }^{e}$ & - & - & - \\
\hline Lagoons & High & High & Low \\
\hline \multicolumn{4}{|c|}{$\begin{array}{l}\text { a The relative risk is modified by population size. Relative risk is increased for discharges from } \\
\text { large populations and decreased for discharges from small populations. }\end{array}$} \\
\hline \multicolumn{4}{|c|}{$\begin{array}{l}\text { b Assumes the design capacity has not been exceeded and that climatic and oceanic extreme } \\
\text { conditions are considered in the design objective (i.e., no sewage on the beach zone). }\end{array}$} \\
\hline \multicolumn{4}{|c|}{$\begin{array}{l}\text { "Includes combined sewer overflows if active during the bathing season (a positive history of } \\
\text { total non-discharge during the bathing season can be treated as "Low") }\end{array}$} \\
\hline \multicolumn{4}{|c|}{${ }^{\mathrm{d}} \mathrm{NA}=$ not applicable } \\
\hline $\begin{array}{l}\text { eAdditional investigations recommer } \\
\text { index organisms. }\end{array}$ & account fo & ly lack of pr & tion with faecal \\
\hline
\end{tabular}


This clearly demonstrates that: (i) an effective outfall is a prerequisit for obtaining a low level of risk to public health; and (ii) from the public health risk standpoint, more advanced treatment than preliminary does not significantly lower the risk. The WHO does not present an opinion regarding secondary treatment followed by disinfection. But as mentioned, the risk of secondary treatment with disinfection is similar to the risk of secondary treatment without disinfection due to the exposure during instances of failures of the disinfection systems (which in developing countries are quite frequent). That means that even if secondary treatment is provided, it should be followed by an effective outfall, however, if an effective outfall is installed, secondary treatmet is not required.

The above referres to public health risks, but it applies also to risks to the marine environment imposed by effluent discharge to the sea, since when taking into consideration the high dilution achieved outside the mixing zone, the discharged contaminants concentrations comply with most of the existing seawater quality standards.

\section{EXAMPLES OF WASTEWATER OCEAN DISCHARGE IN LATIN AMERICA}

Some examples of projects of wastewater discharge to the sea and to large rivers in Latin America are presented in this section, for the purpose of providing information on: (a) the impact of Strategy (ii) on the seawater quality; and (b) economic comparison of Strategy (i) and Strategy (ii).

In Chile, legislation allows discharge to marine waters of an effluent of a quality compatible with that of a preliminary treatment effluent, if the discharge site is located outside the coastal protection zone. As a result, the wastewater management strategy of all the Chilean coastal cities is based on preliminary treatment followed by an effective outfall. About 40 systems of this type are spread along the Chilean coast, the largest being the system which serves jointly the cities Valpa- raiso and Viña del Mar. A five years comprehensive monitoring program of the seawater quality around the discharge point of two outfalls, Penco (serving a population of 40,000 0) and Tome (serving a population of 50,000 ), in the Concepcion Bay in Chile was carried out by the local water utility. The Tome outfall has an internal diameter of $450 \mathrm{~mm}$ and is $1,200 \mathrm{~m}$ long, equipped with a 25 meter long diffuser zone discharging the effluent at a depth of $25 \mathrm{~m}$. The Penco outfall has an internal diameter of $580 \mathrm{~mm}$ and is $1,300 \mathrm{~m}$ long, equipped with a $25 \mathrm{~m}$ long diffuser zone discharging the effluent at a depth of $22 \mathrm{~m}$. The location of the penco outfall and the sampling points around this outfall are shown in Figure 2. The results of the monitoring program of the Penco outfall based on information provided by Leppe and Padilla (1999) are presented in Table 2. The marine water quality composition at 100 meters from the discharge points refers to averages of six measuring points around the outfalls. The results are averages of five years of measurements.

For all quality parameters measured around the Penco outfall, except fecal and total coliforms, concentrations at a distance of 100 meters from the discharge point are the same as background levels. This demonstrates the high treatment capacity of the outfall systems.

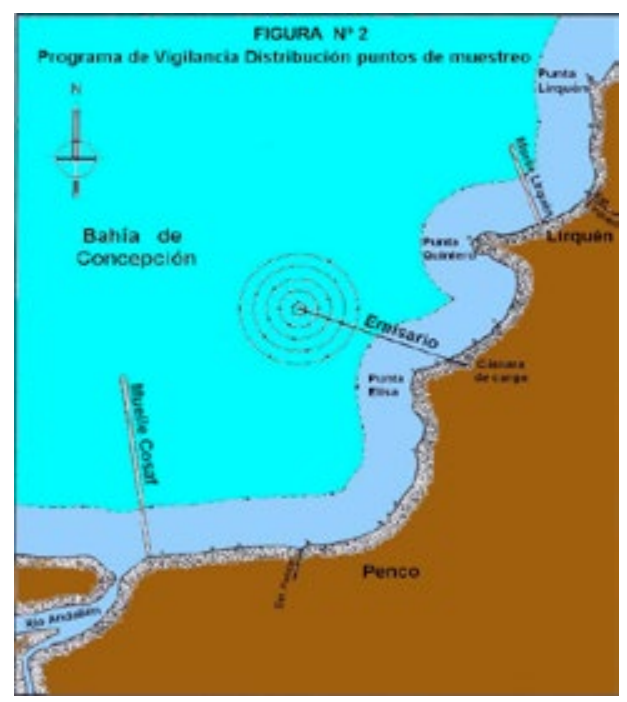

Figure 2: Sampling Points around the Penco Outfall 
The concentrations of coliforms in the raw sewage and preliminary treated effluents are extremely high. Even so, their concentrations are markedly reduced at a distance of 100 meters from the discharge point, to levels that meet the most stringent bathing water standards, although they are still a little higher than the background. With decay, the concentrations reduced to background levels within a short additional distance. The monitoring results of the Tome outfall are similar.

The uniqueness of the Penco and Tome outfalls is that: (i) a comprehensive monitoring program of their performance has been in effect for a long period of 10 years (of which only the resultsof 5 years are reported here); and (ii) water quality was measured not only near the shore, which is the common practice, but also near the discharges at several points located on circles with a radius of 100 meters difference centered at the discharge point. A summary and conclusions of the study of the Penco and Tome outfall is presented in Roberts, Libhaber et al, (2010) PP 428-434, and it includes important material on the prformance of an effective submarine outfall system.

The wastewater management system of the city of Cartagena, Colombian, a city with a population of over one million located on the coast of the Caribbean Sea, consists of an advanced preliminary treatment plant (located inside a closed building as shown in Figure 1) followed by a submarine outfall of $1,800 \mathrm{~mm}$ diameter discharging the effluent at a distance of $2.8 \mathrm{Km}$ from the shoreline, at a depth of about 20 meters. The Colombian legislation requires secondary treatment for wastewater discharged to the sea, but in the case of Cartagena, a license for discharging preliminary effluent was approved for a fixed period of several years, after which the treatment level will have to be upgraded (see below). Detailed information on the Cartagena project is presented in Roberts, Libhaber et al, (2010) PP 414-428, and in Browder and Duvi (2014). A scheme of the Cartagena wastewater management system is presented on the right hand side of Figure 3. The Cartagena wastewater management system went into operation in 2013. Performance results of the system based on water quality monitoring undertaken in 2014 are presented in the left hand side of Figure 3 (source: Browder and Duvi, 2014).

The results show the marked improvement in the quality of the water bodies surrounding Cartagena, including the beaches, the Cienaga de la Virgen coastal lagoon and the Cartagena Bay. Monitoring carried since 2014 show similar results and confirms the positive impact of the system of preliminary treatment followed by the effective outfall on the quality of all the water bodies surrounding Cartagena.

The construction cost of the Cartagena preliminary treatment plant was 15 Million US\$ (MUS\$) and the construction cost of the submarine outfall was 22 MUS\$, resulting in a total investment cost of 37 MUS\$ for the wastewater management system. The O\&M cost of the system amounts to $0.7 \mathrm{MUS} \$$ /year. The investment per capita is about 28.5 US\$/Capita, which is a low investment for a wastewater management scheme of a large city. If upgrading the preliminary treatment plant to secondary treatment is imposed, an additional large investment will be required, which according to our estimates, would amount to about 260 MUS\$ for an upgrade to activated sludge. The operation and maintenance cost of the upgraded system would initially be about 10 MUS\$/Year and would increase to about 13 MUS\$/Year after 20 years. 
Table 2: Marine water quality near the Penco outfall, Concepción, Chile (Average of 5 Years Monitoring)

\begin{tabular}{|c|c|c|c|c|c|}
\hline Parameter & $\begin{array}{c}\text { Effluent } \\
\text { discharged } \\
\text { into outfall }\end{array}$ & $\begin{array}{l}\text { Maximum } \\
\text { according } \\
\text { to local } \\
\text { standards }\end{array}$ & $\begin{array}{l}\text { At the } \\
\text { discharge } \\
\text { point }\end{array}$ & $\begin{array}{l}\text { At } 100 \mathrm{~m} \\
\text { from the } \\
\text { discharge } \\
\text { point }\end{array}$ & $\begin{array}{l}\text { Typical } \\
\text { back- } \\
\text { ground } \\
\text { values }\end{array}$ \\
\hline $\mathrm{pH}$ & 7.4 & $5.5-9.0$ & 7.6 & 7.6 & 8.0 \\
\hline Temperature ${ }^{\circ} \mathrm{C}$ & 18.4 & - & 11.5 & 13.2 & 13.8 \\
\hline Oil and grease $\mathrm{mg} / \mathrm{l}$ & 48.8 & 150 & 4.0 & 5.6 & 3.2 \\
\hline $\begin{array}{l}\text { TSS (Total suspended solids) } \\
\mathrm{mg} / \mathrm{l}\end{array}$ & 216 & 300 & 3.5 & 3.7 & 3.8 \\
\hline $\begin{array}{l}\text { BOD5 (Biochemical oxygen } \\
\text { demand) } \mathrm{mg} / \mathrm{l}\end{array}$ & 236 & - & 2.5 & 2.8 & 2.5 \\
\hline $\begin{array}{l}\text { TOC (Total organic carbon) } \\
\text { mg/l }\end{array}$ & 142 & - & 2.5 & 3.5 & 1.4 \\
\hline DO (Dissolved oxygen) $\mathrm{mg} / \mathrm{l}$ & 1.1 & - & 5.1 & 7.9 & 7.9 \\
\hline Detergents $\mathrm{mg} / \mathrm{l}$ & 15.4 & 15 & 0.05 & 0.07 & 0.06 \\
\hline Nitrogen Kjeldal mg/l & 49.3 & - & 0.5 & 0.36 & 0.4 \\
\hline Nitrites $\mathrm{mg} / \mathrm{l}$ & 0.01 & - & 0.02 & 0.01 & 0.01 \\
\hline Nitrates $\mathrm{mg} / \mathrm{l}$ & 0.15 & - & 0.18 & 0.21 & 0.16 \\
\hline Total Phosphorus, mg/l & 12.9 & - & 0.2 & 0.25 & 0.2 \\
\hline Phosphate, $\mathrm{mg} / \mathrm{l}$ & 39.6 & - & 1.0 & 1.0 & 1.0 \\
\hline Sulfur, mg/l & 0.8 & 5 & 0.18 & 0.25 & 0.22 \\
\hline Phenol & $<0.002$ & 1 & $<0.002$ & $<0.002$ & $<0.002$ \\
\hline Fecal Coliforms, MPN/100 ml & $1.1 \times 10^{8}$ & - & 5420 & 172 & 3.0 \\
\hline Total Coliforms, MPN/ $100 \mathrm{ml}$ & $1.4 \times 10^{8}$ & - & 7317 & 223 & 5 \\
\hline
\end{tabular}

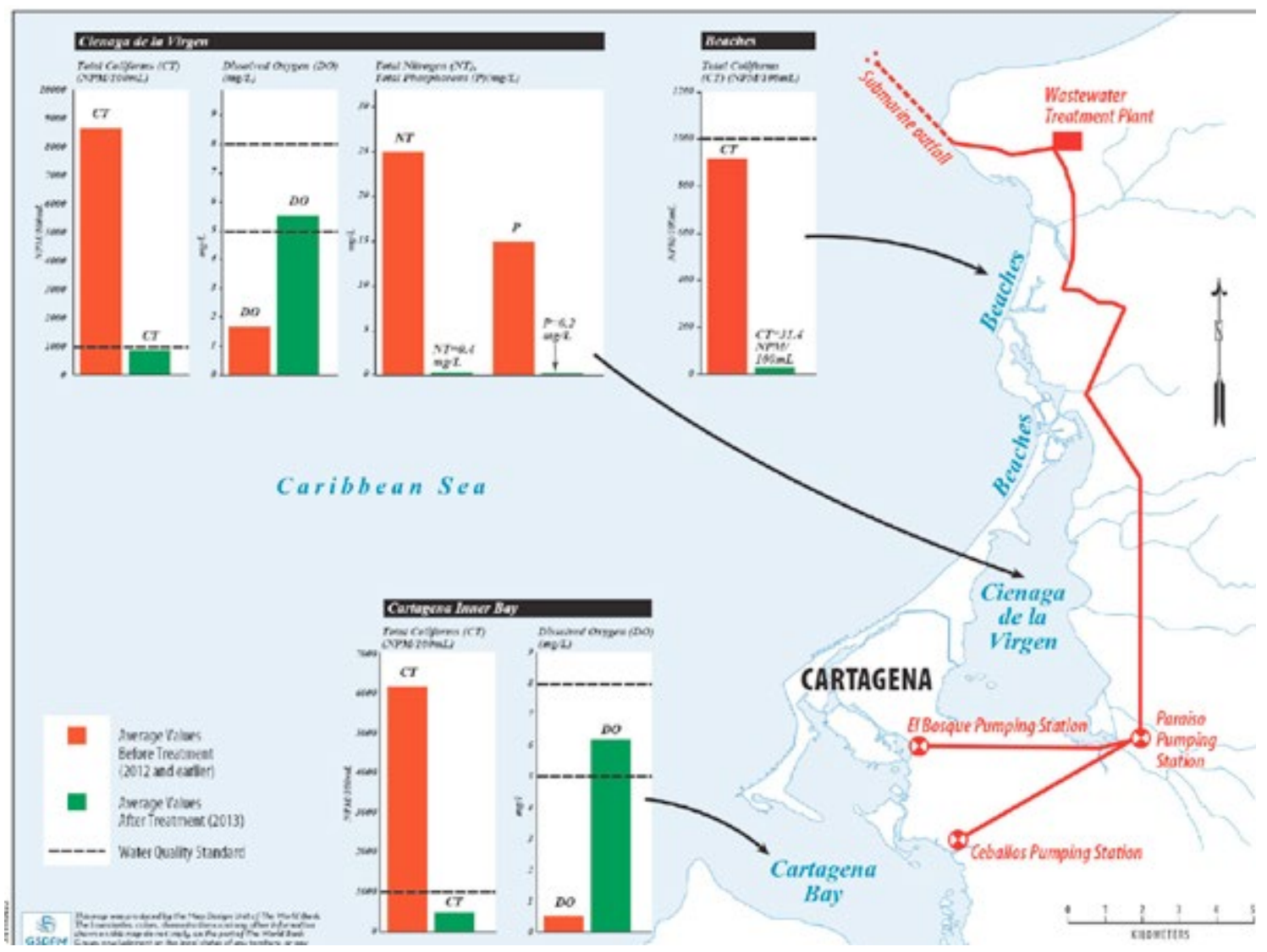

Figure 3: The Cartagena Wastewater Management Installations and Indicative Water Quality Data 
An economic comparison between the two management strategies (the implemented strategy and the strategy of upgrading the existing treatment plant to an activated sludge plant while using the same already constructed outfall) is presented in Table 3.

The results show the meaningful economic benefit of the adopted strategy. In terms of investment cost, the secondary treatment alternative is 7.6 times more expensive than the adopted strategy of preliminary treatment. But the real economic comparison refers to comparison of the net present value (NPV) of the two alternatives, which is the comparison of the life cycle costs of both.

The NPV of the operation of the current Cartagena system is about 52 MUS\$. The NPV of the secondary treatment alternative is about 540 MUS\$, i.e., about 10.5 times higher than that of the current alternative.

Table 3: Economic Comparison of Two Wastewater Management

Alternatives for Cartagena

\begin{tabular}{|c|c|c|c|c|c|}
\hline \multirow{3}{*}{$\begin{array}{c}\text { Wastewater Management } \\
\text { Strategy }\end{array}$} & \multirow{3}{*}{$\begin{array}{l}\text { Source Cost } \\
\text { Data }\end{array}$} & \multicolumn{4}{|c|}{$\begin{array}{c}\text { Cost } \\
\text { (Million US\$) }\end{array}$} \\
\hline & & \multicolumn{2}{|c|}{ Constrution } & \multirow{2}{*}{$\begin{array}{c}\text { O\&M } \\
\text { (per year) }\end{array}$} & \multirow{2}{*}{$\begin{array}{c}\text { Net Present } \\
\text { Value (NPV) } \\
(20 \text { years, 6\%) }\end{array}$} \\
\hline & & Outfal & $\begin{array}{c}\text { Treatment } \\
\text { Plant }\end{array}$ & & \\
\hline $\begin{array}{c}\text { Applied Strategy of } \\
\text { preliminary treatment } \\
\text { followed by an Effective } \\
\text { Outfall } \\
\text { (Strategy ii) }\end{array}$ & $\begin{array}{c}\text { Actual } \\
\text { construction } \\
\text { and OM cost }\end{array}$ & 22 & 15 & 0.7 & 51.7 \\
\hline $\begin{array}{l}\text { Potencial Upgrade Strategy } \\
\text { of Activated Slugde } \\
\text { Treatment followed by an } \\
\text { Effective Outfall } \\
\text { (Strategy i) }\end{array}$ & $\begin{array}{l}\text { Author's } \\
\text { estimate }\end{array}$ & 22 & 260 & $\begin{array}{l}10 \text { during } \\
\text { initial years } \\
13 \text { during } \\
\text { final years }\end{array}$ & 541.7 \\
\hline
\end{tabular}

If forced to upgrade the treatment plant at an investment of 260 MUS\$, Aguas de Cartagena, the water utility of Cartagena, would financially collapse. Even if the additional investment would be provided by the government as an investment subsidy (which is not likely to happen) the additional O\&M cost of the activated sludge system would worsen the financial standing of the utility. But most importantly, the upgrade would not provide any public health and environmental benefits.

In Lima, the capital of Peru, a city with a population of over 8 million, two submarine outfall systems were recently constructed: (i) the Taboada system which entered into operation in 2013 and serves a population of about 5 million; and (ii) the La Chira system which is planned to initiate operating in 2016 and is designed to serve a population of about 2.7 million. Both systems are based on an advanced preliminary treatment plant followed by an effective outfall. The investment cost of the Taboada system was about 150 MUS\$, of which 90 MUS\$ refer to the outfall and 60 MUS\$ to the preliminary treatment plant. The O\&M cost of the Taboada system is about 4 MUS\$/Year. The investment per capita is about 30 US\$/Capita, which is similar to that of Cartagena and is also a low investment for a wastewater management scheme of such a large city. 
Buenos Aires, the capital of Argentina, a city of about 12 million people located on the bank of the La Plata River, represents an interesting case. AYSA, the city's water and sanitation utility is implementing a wastewater management project consisting of constructing two preliminary treatment plants followed by two long subaquatic outfalls of about $10 \mathrm{~km}$ long each (at two different locations) for discharge of the effluents to the La Planta River. The same river is also the water supply source of the city. Using water quality modeling, the location and length of the outfalls was established in such a way that the discharged effluents will not affect the water quality at the withdrawing points for the water supply system. If this approach was adopted in the case of discharge of effluent into a water body which serves as the potable water source for such a large city, it can most probably be applied in cases where the waster body serves for bathing and recreation.

The city of Montevideo, the capital of Uruguay, discharges its wastewater to the La Plata River through two systems, each consisting of a preliminary treatment plant followed by a subaquatic outfall. In Brazil, several systems of preliminary treatment plants followed by an outfall discharging the effluent to the ocean are in operation. Those include the Ipanema outfall system in Rio de Janeiro, The Santos, Guaruja and Praia Grande outfalls in the Baixada Santista, and a large outfall in the state of Bahia.

The outfall systems of Santa Marta in Colombia and of Sosua in the Dominican Republic represent special cases. The sea bottom slope in front of these cities is steep so at a short distance from the shoreline the water depth is over 50 meters and in such conditions an effective outfall can be short. The Santa Marta outfall is $\mathbf{5 0 0}$ meters long (see Roberts, Libhaber et al, 2010, PP 434438) and the Sosua outfall is 780 meters long. The treatment level in both cases is preliminary and the investment in the wastewater management systems was small.
Recent examples of projects which are based on higher than preliminary level of treatment prior to discharge of the effluents to large receiving bodies are the following:

A large city in Latin America located on the bank of a large estuary is now implementing a wastewater management project for a population of about 1.1 million (about half of the city's population). The adopted strategy is construction of a chemically enhanced primary treatment (CEPT) plant on the bank of the estuary and discharge of the effluent to the estuary through a 650 meters long outfall made of a 2.4 meters diameter pipe trenched in the bottom of the river, with a diffuser section at the last 90 meters of the outfall.

An alternative strategy of using a preliminary treatment plant followed by the same outfall was also studied. Based on modeling of the estuary water quality it was found that the impact of the two alternatives on the estuary water quality was identical and both complied with the country's estuaries and marine waters quality standard. However, the preliminary treated effluent does not comply with the country's effluent quality standard, which requires that all treatment plants produce an effluent containing no more than 100 $\mathrm{mg} / \mathrm{l}$ of BOD and TSS and no more than 1,000 MPN/100 ml total coliforms. Coincidently, the raw water is quite diluted, containing about $125 \mathrm{mg} / \mathrm{l}$ BOD and about the same concentration of TSS.

The estimated cost of the adopted CEPT treatment plant is about 90 MUS\$ and the estimated O\&M cost of the plant is about 7 MUS $\$ / Y e a r$, while the estimated cost of an advanced preliminary treatment plant is about 30 MUS\$ and its O\&M cost is about 0.6 MUS\$/Year. The economic advantage of the preliminary treatment alternative is significant, but it was rejected for the purpose of obtaining an effluent quality which conforms to the effluent quality standard. What is the environmental benefit induced by the standard in this case? The effluent will flow inside a section of a 
land pipe about 500 meters long before entering the outfall. The CEPT treatment will ensure that the effluent flowing in the pipe will not contain more than $100 \mathrm{mg} / \mathrm{l} \mathrm{BOD}$ and TSS. But there will be no negative impact on the pipe or on the environment if the BOD and TSS concentrations inside the pipe were to be a little higher than $100 \mathrm{mg} / \mathrm{l}$. However, to comply with the standard (an act which has no benefit in this case) an additional investment of about 60 MUS\$ and an additional annual cost of about 6.4 MUS\$/Year will be spent. On top of its economic disadvantage, the selected alternative will also generate a severe environmental problem by producing 94 ton/day of raw CEPT primary sludge, which required a lot of efforts for adequate treatment and safe disposal.

In another city with a population of 500,000 located on the bank of the Amazon River (not in Brazil), the construction of the new wastewater management system was recently completed. The system consists of a complex secondary treatment plant whose effluent will be discharged to a large tributary of the Amazon through a subaquatic outfall, through a discharge point located at a distance of $3.3 \mathrm{Km}$ from the confluence of this tributary with the Amazon. The cost of this system was about 110 MUS\$, all of it provided as an investment subsidy from various government agencies. A preliminary treatment plant would have been sufficient in this case, saving about 80 to 90 MUS\$, which could have been invested in urban upgrading in the large poor neighborhoods of this city. It is also doubtful that the local water and sanitation utility will be able to finance the O\&M costs of the treatment plant. Unfortunately, there is no bypass from the preliminary treatment unit to the pumping station which conveys the effluent to the outfall. It might be a good idea to provide, for operational purposes, in each coastal treatment plants of higher than preliminary treatment level, a bypass connecting the preliminary treatment unit's effluent to the final effluent discharge point of the plant.
Roughly, it is estimated that the ratio of investment cost in the strategy of secondary treatment followed by an effective outfall to investment cost in the strategy of preliminary treatment followed by an effective outfall is in the range of 6 to 15 . The low value refers to the condition of a mild bottom sea slope (which requires a long outfall) and the high value refers to the condition of a steep bottom sea slope (which requires a short outfall).

The ratio of investment cost in a strategy of less than secondary treatment (but higher than preliminary) followed by an effective outfall to investment cost in the strategy of preliminary treatment followed by an effective outfall is in the range of 3 to 7 . The low value refers to the condition of a mild bottom sea slope (which requires a long outfall) and the high value refers to the condition of a steep bottom sea slope (which requires a short outfall).

\section{OVERCOMING RESTRICTIONS OF NORMS AND REGULATIONS}

The political economy favors imposing the application of a complex and expensive wastewater management strategy. Ministries of the environment, which formulate and enact the effluent quality standards, always prefer adopting the most stringent standards (considering it to be safer) and they do not take into account financial implications of overly stringent standards. Usually they copy the most stringent standards from developed countries. Universities teach students the cutting edge technologies of wastewater treatment, and the graduates' tendency is to prefer such technologies. Consulting firms prefer larger and more complex projects, and decision makers have sometimes their own reasons to prefer more expensive projects. In spite of all that, surprisingly, there are many cases in Latin America of implementation by coastal cities of the strategy of preliminary treatment followed by an effective submarine outfall. 
A condition for succeeding to implement the strategy of preliminary treatment followed by an effective submarine outfall is the existence of a champion who favors this strategy. That can be the managing director or the chief engineer of the water and sanitation utility, or the politician in charge of making the decision, or the representative of the institution which provide financing for the project (in case this person has knowledge and understanding in the matter). A champion supporting the strategy of preliminary treatment followed by an effective outfall can try and convince the authorities to approve this strategy in one of the following ways:

(a) convince the authorities that complying with effluent quality standards should take into account the need for staged development of the treatment systems. Wastewater management must be developed in stages in accordance with the availability of financial resources and capacity, while taking into account in the first stage the assimilation capacity of the receiving bodies, so that the stringent effluent standard are achieved after time, at the ultimate project stage, while maintaining reasonable environmental standards at the first stages. Even developed countries went through such a staged process. It is better to start with a first stage that does not fully comply with the regulation than to delay, because of lack of sufficient funding, the initiation of works well into the future while subjecting the population (especially the poor) to many additional years of severe health risks, and the environment to high levels contamination. If the staged approach is accepted, then after operating the first stage it can be proved through environmental monitoring that upgrading the preliminary treatment to secondary treatment is unnecessary. This approach was taken in the projects of Cartagena, Colombia and Bella Vista, Asuncion, Paraguay. In Cartagena, the Colombian legislation required secondary treatment prior to discharge of effluent to any surface water receiving body. After a lot of efforts on part of the water and sanitation utility, the local environmental authority issued the environmental license for the wastewater management project permitting the construction of a first stage consisting of preliminary treatment followed by an effective outfall and operating it until 2015, a year in which the treatment level needs to be upgraded to higher than preliminary. As happens with most wastewater management projects of large cities, project construction took a long time because it included construction of the secondary sewage networks, some large pumping stations, the main wastewater collection and conveyance system and the treatment plant. Consequently, the construction of the treatment plant and of the outfall was completed in 2013, the year in which the system went into operation. Since then the environmental authority is monitoring all the water bodies surrounding Cartagena, and as shown above, the quality of all the water bodies, including the Caribbean Sea, significantly improved since the treatment plant went into operation. It became clear that upgrading the treatment plant to secondary treatment will not further improve the quality of the water bodies. The requirement for upgrade is currently on hold.

(b) convince the authorities to provide a waiver to a specific project without modifying the environmental legislation. Modifying legislation can be a difficult task but obtaining a waiver for a specific project can be easier. This was the case in the Taboada and La Chira large outfalls of Lima, Peru. The government decided to obtain financing for the Taboada project from the private sector through a BuildOperateTransfer (BOT) contract. The proposals received in response to the bidding process were all based on preliminary treatment followed by a long outfall, while only one was based on secondary treatment followed by a short outfall, and it was much more expensive than the others. The government had to confront the dilemma and consulted with several experts. Based on the advice received it decided to approve the 
lowest cost proposal which referred to preliminary treatment followed by a long outfall. In order to accept the lowest cost proposal, a waiver was given to outfall projects in Lima. Based on this waiver, the La Chira system was constructed under the same principle.

Arranging for authorities a demonstration tour to other countries in which projects of preliminary treatment followed by an effective outfall are in operation may also help in convincing that this strategy is viable. This was also part of the strategy in Cartagena.

\section{MANAGING SOCIAL RISKS}

As mentioned, Wastewater management Strategy (ii) also provides social benefits by enabling resolving wastewater problems expeditiously and with a lot of savings, thus liberating the saved funds to solve other social problems. However, as in any wastewater disposal project of a large city, an ocean disposal wastewater project may generate opposition from various interest groups. In this type of projects, opposition occurs during the preparation and construction stages, resulting from misunderstanding of the project, especially of the hydrodynamic concepts. At the operation stage opposition dissipates because no damages or damaging environmental effects occur.

Opposition in developing countries to wastewater disposal through a submarine outfall preceded by preliminary treatment will often prevent any progress at all towards improving wastewater management and disposal. This is because treatment above and beyond preliminary would render most projects financially non-viable. Avoidance of actions towards solving wastewater disposal problems is the worst option of all, and usually leaves the most vulnerable population (mostly the poor) under the worst conditions.

While considering the use of submarine outfalls for wastewater disposal, the possibility of opposi- tion of the public and of other interest groups, as well as other social risks to the project, should not be ignored. Actions to control social risks need to be part of project planning and need to be implemented at the outset. A project component should be designed to address public opposition by providing and disseminating to the community and other stakeholders project information and project studies results, especially the environmental studies, to inform them about the project benefits and the absence of negative environmental impacts, and to gain public acceptance.

As an example, social activity actions undertaken in the Cartagena project were the following:

- Expansion of the participatory approach and working with the community to provide information regarding the impact of the outfall and its benefits (about 250 events were carried out);

- Execution of a publicity campaign regarding the outfall, including publicity in the media (articles in newspapers, advertisements in radio and on TV), preparation and distribution of brochures, etc.;

- Implementation of the social community development program of the project including: (i) support for urban rehabilitation, improvement of sanitary conditions and cleanup activities; (ii) strengthening and development of community organizations to promote participation and social control; and (iii) promotion of community development to consolidate communities, and avoid or reduce conflicts, and to recover cultural heritage, mainly by rehabilitating the Cienaga de la Virgen coastal lagoon;

- Organization of a study tour for community leaders and representatives of the media, the municipality, the environmental authorities, and other stakeholders to similar outfalls sites 
operating in Latin America. The group included about 30 persons that visited outfalls in Chile (Viña del Mar, Valparaiso, and Concepción,), Montevideo in Uruguay and Guaruja in Brazil. All these outfalls are of comparable size to that which was proposed for Cartagena and have the same type of preliminary treatment. Unlike Cartagena, all of them are located in front of the most desirable residential areas and beach resorts, whereas in Cartagena the outfall is located about $20 \mathrm{~km}$ north of the city in a zone which is not a beach resort. In all sites visited the outfalls are functioning successfully, to the complete satisfaction of all the local stakeholders;

- Utilization of a panel of five international experts (hired to review the project), with broad experience in wastewater management, design and construction of ocean outfalls, water quality and oceanographic modeling and environmental impact assessment. The panel provided valuable support in clarifying the technical issues to the various stakeholders.

- Execution of a series of workshops with the opposition groups to explain the scientific, technical and engineering aspects of the selected alternative and its advantages over all others; and

- Financing the participation of representatives of the key stakeholders in an international course on the submarine outfall alternative for final disposal of sewage in coastal cities in the Caribbean, organized at the time by PAHO/ WHO in Barbados.

\section{REFERENCES}

Arodys Leppe Z., Liliana Padilla B. (1999). “Emisarios Submarinos de Penco y Tome, 5 Años de Vigilancia y una Evaluación Global de sus Efectos Ambientales", XIII Congreso Chileno de Ingenieria Sanitaria y Ambiental, AIDIS, Antofagasta, Chile, October 1999. ("The Submarine Outfalls of Penco and Tome, 5 Years of Monitoring and Global Evaluation of their Environmental Effects”, XIII Chilean Congress of Sanitary and Environmental Engineering, AIDIS, Anrofagasta Chile, October 1999).

Browder G, Duvi R. (2014) “Restoring the coastal environment in Cartagena, Colombia”. Latin America and Caribbean Region Environment and Water Resources occasional paper series. Washington, DC; World Bank Group.

http://documents.worldbank.org/curated/en/2014/01/ 19308017/restoring-coastal-environment-cartagena-colombia

Libhaber M, Roberts J.W.P. (2002) "Social Aspects of Wastewater Submarine Outfalls in Developing Countries: The Case of Cartagena, Colombia”, $2^{\text {nd }}$ International Conference of Marine Wastewater Discharge, MWWD, Istanbul.

Roberts J.W.P, Salas J.H, Libhaber M, Reiff M. F, Labe A, Thomson C. J, (2010), "Marine Wastewater Outfalls and Treatment Systems", IWA Publishing.

United Nations (2003). "Word Urbanization Prospects: The 2003 Revision Population Database.” Department of Economic and Social Affair/Population Division.

WHO (2003). "Guidelines for Safe Recreational Water Environments. Volume 1, Coastal and Fresh Waters." World Health Organization. http://www.who.int/water_sanitation_health/bathing/ srwe1/en/ Geneva, Switzerland, p. 80. 